ACTA UNIVERSITATIS LODZIENSIS

FOLIA LITTERARIA POLONICA 8(38) 2016

http://dx.doi.org/10.18778/1505-9057.38.09

Przemysław Dakowicz

\title{
Różewicz and Bonhoeffer. On the Margin of the Poem Learning to Walk by Tadeusz Różewicz
}

\author{
Text for today: "It is good for me that thou has humbled me, that \\ I may learn thy justifications". (Psalm 118:71). \\ These are my favourite words from my favourite Psalm. \\ Dietrich Bonhoeffer
}

Nearby the Wroclaw market square, at the intersection of Odrzańska and Saint Nicolas streets, connected with the arch of the gate leading formerly to the churchyard, there are two small tenement houses from the $15^{\text {th }}$ century. The gate, by which in 1420 the participants of the plebeian rebellion against a German patriciate of the city, was probably built at the same century as the houses adjoined to it. At the beginning of the $18^{\text {th }}$ century it was rebuilt in Baroque style, and the architect Krzysztof Hackner, the author of the rebuilding project, placed on its cornice putti keeping carved stone in cartouche a Latin inscritption "Mors ianua Vitae" ("Death as a Gate of Life"). The cemetery was closed five years later. The tenement houses, called today "Hansel" and "Gretel", were taken years ago by altarists from Saint Elisabeth.

"Hansel", the smaller of the tenements, is situated in Saint Nicolas Street. It consists of three storeys. Its architectural decor is very simple - the facade devoid of adornments, stone frames of windows and gates, pitched roof. It came into being from two buildings, and its current shape owes to a conversion carried out at the end of the $16^{\text {th }}$ century. Formerly it adjoined a cemetery wall. Today it is surrounded with a low cast-iron fence from the church square. Up to 2011 in rooms of "Hansel", also called the House of Chalcographer, Eugeniusz Get-Stankiewicz, outstanding graphic artist and poster-designer ran his workshop, taught students and lived there. Stankiewicz's guests were people of culture - artists, editors of journals, publishers and writers. Not infrequently the place was visited by Tadeusz Różewicz, whom Get-Stankiewicz helped prepare an installation designed

* Dr, University of Lodz, Faculty of Philology, Institute of Polish Philology, Department of Romantic Literature and Tradition; e-mail: pdakowicz@poczta.onet.pl 
by the poet, entitled Nowosielski's Stone. Its photograph was placed on the front cover of a collection of poems published in 2004 entitled Exit.

"Hansel's" windows overlook the Garrison church to the north (formerly Saint Elisabeth) and "Gretel", higher and bigger of the two tenement houses. It comes from the $15^{\text {th }}$ century and similarly to "Hansel" was converted in the $16^{\text {th }}$ century. Originally it was one of many one-and-half-storey houses on the eastern side of the churchyard. In 1564 (this date is visible on first floor window grill), the tenement house was extended with the second floor and pitched roof. Windows were adorned with stone frames, a capital of the Romanesque column was built into the southeastern, which came from Benedictine abbey in Ołbin demolished in fear of Turks. The mid- $18^{\text {th }}$ century brought about another conversion - the third floor, Baroque stuccos, stone portal on the west were added. Today, it houses the Wroclaw Lovers Society, a gallery and a small pub. In summer, a cafe garden shows up under the trees. Tadeusz Różewicz mentioned it in a poem entitled learning to walk:

$\begin{array}{ll}\text { siedzieliśmy w cieniu drzew } & \text { [we sat in the shade of threes } \\ \text { w małej piwiarni koło kościoła } & \begin{array}{l}\text { in a small beer garden near } \\ \text { świętej Elżbiety }\end{array} \\ \text { (transl. Bill Johnston) } & \text { St. Elisabeth's] }\end{array}$

The temple towers over the square, "Hansel" and "Gretel". It was built at the turn of the $15^{\text {th }}$ century. It is the third church in that place (the first was raised soon after foundation of the city, in the mid- $13^{\text {th }}$ century). From 1525 to the end of Second World War Protestants used to say their prayers there. Once it bore a name of Evangelical Cathedral of Silesia. Today it is a garrison church. It preserved the biggest number of epitaphs and bourgeois tombstones of this region. From the top of the tower one can see Wroclaw panorama of more than 80 metres.

Only a few granite tiles separate the chairs of the beer garden "Gretel" from a monument standing at the church square. Somebody who is looking at it from a certain distance, can notice that the monument has a shape of a cross with short and irregular beams. When one observes it up close, they will see the outline of a human body, a kneeling figure without hands or head. If the monument - a precise copy of a Karl Biedermann monument standing near Zionkirche in the capital of Germany - had a head, the face would face westward, to Berlin. In the stone, on which the cast of kneeling figure was placed, the following words in Polish and German were engraved: "For Dietrich Bonhoeffer", "Für Dietrich Bonhoeffer".

Who was Dietrich Bonhoeffer, whom the poet "met in Wroclaw" ("siedzieliśmy w cieniu drzew / w małej piwiarni koło kościoła / świętej Elżbiety // Bonhoeffer czytał mi / swoje wiersze pisane w Tegel" / "we sat in the shade of

${ }^{1}$ All the excerpts of learning to walk I am quoting after: P IV, pp. 250-255. 
trees / in a small beer garden near / St. Elisabeth's/ Bonhoeffer read me/the poems he wrote in Tegel" [transl. Bill Johnston]) and whom he dedicated the most important poem of the collection Exit - learning to walk?

\section{Bonhoeffer}

He was born in Wroclaw, on $4^{\text {th }}$ February $1906^{2}$ as the sixth child of Paula, née von Hase, and Karl Bonhoeffer. Dietrich's father was an outstanding psychiatrist and neurologist consistently opposing psychological "inventions" of Freud and Jung. His mother came from a venerable Prussian family, which members were willingly interested in music and art (Amongst them there were two painters - Stanislaus and Leopold Kalckreuth). Her father, Alfred von Hase, held the office of Wilhelm II's court preacher, but he resigned when the emperor ordered that "sermons should be preached only to him, and he called bluntly the proletariat "skunk"” (Morawska, p. 11) .

The Bonhoeffers lived on Bartel Street at number seven, near the river. A that time the capital of Silesia was officially referred to as the Royal Capital and Residentiary City of Wroclaw. In the year of Dietrich Bonhoeffer's birth, it was chosen to be the headquarters of Wilhelm II's army training. Then also - for the Emperor's special invitation - the 30-year-old Winston Churchill was received in the city ${ }^{4}$. In 1913, Jahrhunderthalle (today Centennial Hall) was opened with great ceremony, where a centenary of the liberation war was held. "The ceremonies were started with an exhibition of Napoleonic memorabilia totalling 7240 items - the main attraction was the French Emperor's carriage. The central event was supposed to be a premiere of Gerhard Hauptmanna's play"5, a Nobel Prize winner in literature

${ }^{2}$ I derive biographic information from two monographies, first of which was written by Bonhoeffer's teacher, an audience of famous letters with TegeK and propagator of Nachfolge author's work, another one by indefatigable advocate of Polish-German reconciliation, outstanding catholic journalist and many years' co-worker of "Tygodnik Powszechny”: E. Bethge, Dietrich Bonhoeffer. Świadek Ewangelii w trudnych czasach, transl. ks. B. Milerski, Augustana, Bielsko-Biała 2003 (in the text I am using abbreviation: "Bethge"); A. Morawska, Chrześcijanin w Trzeciej Rzeszy, Biblioteka "Więzi", Warsaw 1970 (abbreviation: "Morawska"). This article - superficial and short - it would not have come into being without Bethge and Morawska's books. Shown by me a shortened version of Bonhoeffer's biography is basically a summary of the two mentioned researchers' conclusions.

${ }^{3}$ Authors of the most famous in recent years work about the history of the Silesian capital, described Emperor Wilhelm II as follows: "he had a bipolar personality and suffered from an inferiority complex, and his imprudent speeches and tactless comments ignited consternation in the country and abroad" (N. Davies, R. Moorhouse, Mikrokosmos. Portret miasta środkowoeuropejskiego. Vratislavia-Breslau-Wroctaw, transl. A. Pawelec, Znak, Cracow 2002, p. 302).

${ }^{4}$ Ibidem, p. 306.

${ }^{5}$ Ibidem, p. 328. 
connected with Wroclaw, but in the nick of time its production was stopped. The pacifist meaning of that work was in obvious and clear opposition with the atmosphere in the imperial court. Wroclaw was preparing for war. At that time the Bonhoeffers were not living there anymore. In 1912, they moved to Berlin where professor Karl Bonhoeffer assumed the chair of the faculty of psychiatry.

In the capital of Germany, which soon became Dietrich's hometown, they lived in Brückenallee Street. After four years they moved to Wangenheim Street. "This neighbourhood was a district of professors. Nearby [...] lived the physicist Max Planck, the theologist Adolf von Harnack, professors of medicine His and Hertwig and the historian Hans Delbrück" (Bethge, p. 14).

The atmosphere at home, where intellectual liberalism dominated, with official church circles they were in contact only during important religious family celebrations, and "they went very rarely to the church" (Morawska, p. 41), did not favour - it appears - a genuine participation in Christian life. Neither brothers and sisters nor Bonhoeffer's parents could expect that he would choose the arduous way of theological studies. Eberhard Bethge assumed rightly that the decision of the future Nachfolge author to become a clergyman (choice in the eighth form of Hebrew language as elective was supposed to be explicit with final defining his life path) could influence traumatic family experiences from First World War - two of his brothers joined the army, and one of them, Walter, died from his wounds on $28^{\text {th }}$ April 1918. As the biographer implied, certain meaning could have the fact that - as the youngest son - Dietrich wanted to "prove, involving [forces] in a different area than his brothers" (Bethge, p. 18).

In 1923, Bonhoeffer started theological studies in Tübingen. He devoted himself especially to reading philosophical works. During classes conducted by Reader Karl Gross he delivered a speech on Kant's Critique of Pure Reason. At that time, the views of Karl Barth, who in the near future was to become a Bonhoeffer's teacher and master of theological art and somebody with whom he had to hinder, argue and discuss, were winning renown through protestant theologians.

In 1924, after a several-month-long visit in Rome, Bonhoeffer continued his studies at the University in the German capital. Three years later he defended his doctoral dissertation entitled Sanctorum Communio, and when he passed his first church examination, he devoted himself to priest work with children. In 1928, he went to Spain where for a year he worked in a parish in Barcelona, "dealing with the most peculiar people [...]: globetrotters, vagabonds, wanted criminals, mercenaries from the Foreign Legion, tamers of lions and other predators [...], German

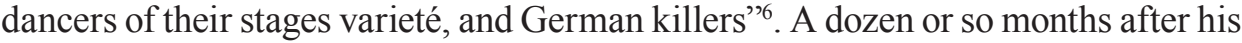
return he finished and defended his postdoctoral dissertation entitled Act and Being.

${ }^{6}$ D. Bonhoeffer, Widerstand und Ergebung. Briefe und Aufzeichnungen aus der Haft., Christian Kaiser Verlag, München 1970. As cited in: Bethge, p. 24. 
At that time an opposition towards "routinised Christianity" deepened in him (Morawska, p. 43), the progress of which he could observe. It was "the impatience of active, socially and intellectually lively human" with a religion which started "making himself in practice as bland, indifferent to earthy things doctrine of mediocre people, living in a closed world of its excogitated artificially abstractions and juridisms, restraining any spontaneity, freedom, life itself" (ibidem). He could not cope with the fact that in his contemporary world Christianity changed into a set of meaningless gestures, incomprehensible and actually ignored ethical principles, dead formulas of official religiousness, which was not connected with secular life and did not influence any everyday choices made by members of the Church.

In September 1930, he left for New York for an year-long scholarship at the Union Theological Seminary. The meeting with American Protestantism was for him an experience which enabled him to look at the German Church and European Christianity from a different perspective. As Eberhard Bethge wrote, "Bonhoeffer had mixed feelings towards this trip: on the one hand curiosity, on the other hand pride resulting from conviction of superiority of German theology over American seminars, which had ethical character, not strictly theological" (Bethge, p. 27). Especially typical in the context of Bonhoeffer's American trip seems to be the fact that author of Act and Being would soon become the most consistent defender of Christian morality in the Nazi Third Reich, upholding unshakeably principles, which nothing and nobody - even a leader enjoying idolatrous adoration of the people - cannot withdraw, trample or at least call into question. This dislocation of accents from a speculative theology University circles go in, moving very often between conception and theories which do not have anything in common with reality, into ethics, emphasizing the need of using the essential principles of faith in everyday life, which consists in constant standing of the individuals towards the necessity of making a choice, conviction of superiority of Christian imperative to follow God carrying the cross, made that at the turn of thirties and forties Bonhoeffer finally undertook the burden of responsibility for fate of his nation and became involved in anti-Nazi conspiracy. Before it happened, in all ways possible for a Lutheran minister he tried to fight for a proper, built on an authentic Christian basis, shape of political and social reality of Germany in the 1930s.

In 1932, NSDAP which was growing in strength proposed Hitler as a candidate in the presidential election. He did not manage to win it (in the second runoff Hitler received $36.8 \%$ to $53 \%$ of votes given for Hindenburg), but an efficient propaganda machine of the Nazis contributed to a big success of that political party in the following, July parliamentary elections ${ }^{7}$. Göring, who managed to

${ }^{7}$ Cf. M. Steinert, Hitler, transl. K. Skawina, Ossolineum, Wroclaw 2001, p. 195. In further excerpts of this text concerning taking power by Hitler I use information included in this monography. 
persuade the members of the Hohenzollerns dynasty to actively engage in the Nazi movement, became Reichstag Chancellor. In the meantime, Hitler refused to take an office of vice-chancellor, did not agree to become a chancellor, when this office was proposed to him by the German Centre Party. Finally in January 1933, after consultations with previous chancellor von Papen and Hugenberg, as well as the Reichswehr, Farmers Union and the entrepreneurs community, he decided to form a coalition government. Hindenburg agreed on his swearing ceremony ${ }^{8}$. On $30^{\text {th }}$ January Joseph Goebbels wrote in his diary: "We are at the objective. The German revolution has begun"9.

Bonhoeffer was then an assistant professor in the Faculty of Theology at the Berlin University, he worked as an academic priest and preacher. In September 1931, during an ecumenical conference in Cambridge, he was chosen for a secretary to "matters of ecumenical cooperation of youngsters" (Bethge, p. 31), and his engagement in ecumenism and pacifism, similarly more and more violent opposition towards the practices of German ruling class, were rising.

On 1 February, two days after Hitler took the office of chancellor, he talked in the Berlin radio about the transformations of commander conception. Critical towards new leaders, the speech was not shown as a whole, the broadcasting station interrupted its broadcast. Twenty seven days later he preached a sermon in The Holy Trinity Church in Berlin for the end of the winter semester. He responded there to Gedeon. That Israeli hero, son of Joel from the House of Abiezer, demolished the Baal altar, which Israelites idolized, and having at his disposal a small handful of soldiers liberated his people from a seven-year-long Midian captivity. Humility and obedience in service to God, which characterized Gedeon, Bonhoeffer set against the strength and pride of terrestrial kings, personified by Siegfried, a character from an old-Germanic epos about Nibelungs. References to the political situation were clear:

In the Church we have only one altar, the altar of the Most Reverent, the One and only, the Almighty, the Lord, to whom alone be honour and praise. The Creator before whom all the creation bows down, before whom even the most powerful are but dust. We don't have any side altars at which to worship human beings. The worship of God and not of humankind is what takes place at the altar. of our church Anyone who wants to do otherwise should stay away and cannot come with us to the God's House. Anyone who wants to build an altar to himself or to any other human is mocking God, and God will not allow such mockery. To be in the church means to have the courage to be alone with God as Lord, to worship God and not any human

\footnotetext{
${ }^{8}$ Ibidem, pp. 196-198.

9 J. Goebbels, Die Tagebücher: Sämtliche Fragmente, E. Fröhlich (ed.), München 1987, vol. 2 , pp. 360-361. As cited in: M. Steinert, p. 200.
} 
person. And it does take courage. The thing that most hinders us from letting God be Lord, that is, from believing in God, is our cowardice. That is why we have Gideon, because he comes with us to the one altar of the Most High, The Almighty, and falls on his knees to this God alone.

In the church we have also only one pulpit, from which faith in God is preached and not any other faith, not even with the best intentions. This again is why we have Gideon - because he himself, his life story is a living sermon about his faith. We have Gideon because we don't always want to be speaking of our faith in abstract, otherworldly, unreal, or general terms, to which people may be glad to listen but don't really take note of; because it is good once in a while actually to see faith in action, not just hear what it should be like, but see how it just happens in the midst of someone's life, in the story of a human being. Only here does faith become, for everyone, not just as children's game, but rather something highly dangerous, even terrifying. Here a person is being treated without considerations or allowances; he has to bow to what is being asked, or he will be broken. This is why the image of a person of faith is so often that of someone who is not beautiful in human terms, not a harmonious picture, but rather that of someone who has been torn to shreds. The picture of someone who has learned to have faith has the peculiar quality of always pointing away from the person's own self, toward the One in whose power, in whose captivity and bondage he or she is. ${ }^{10}$

(Transl. Douglas W. Scott)

Dietrich Bonhoeffer prepared himself to undertake in his own life the fate of the conqueror of Midianites and a steadfast God servant. He desired to be a Gideon. He seemed to have profound, almost prophetic awareness that in times which were to come, the only solution for any honest man, man of strong faith, would show with himself an image which is "not beautiful, inharmonious, torn into shreds".

In the meantime the next day after preaching a sermon in The Holy Trinity Church in Reichstag the fire broke out. Until today it is not clear who was actually responsible for it. The results of that accident appeared to be vital - four thousands communist activists arrested (including the President of KPD) and delegalisation of communist press.

Among the electoral excitement which yet again captured Germany, when the President decided to announce new elections, particularly explicitly sounded the voice of Hitler, Chancellor of the Reich. Each of his speeches and appearances were live broadcasted by every German radio station. Goebbels, Gauleiter of Ber-

${ }^{10}$ D. Bonhoeffer, Wybór pism, Selection, edition and introductory notes by A. Morawska, Znak, Cracow 1969, pp. 61-62. 
$\operatorname{lin}^{11}$, ensured it. "NSDAP and Black-White-Red Fight Front (Kampffront), uniting different right-wing groups, achieved in total $51.8 \%$, of which $43.9 \%$ votes were given to the Nazis [...] All in all, 17.3 million Germans voted for Hitler"12.

The day of the election triumph became for the Nazis an actual beginning of a revolution which was supposed to free Germany from the spectre of communism and ensure the members of NSDAP an absolute power in the country. At the same time, as Anna Morawska correctly pointed out, the first weeks after Reichstag fire were a unique "psychological moment, in which they devoted themselves to a blind service for a strong leader who could seem to be the only and liberating solution for many democrats and rationalists" (Morawska, p. 55).

In March 1933 the government set to work out a bill on "unlimited authorities"13. It was supposed to be a legislative response to an "chaos", which - as the Nazis argued - could capture the country. So as not to permit the negative reactions in the country and abroad, it was necessary to find a support the project by the German Centre Party ${ }^{14}$. Negotiations were started, during which many promises were made to the representatives of the party - among others, a guarantee of Christian education, "maintaining the prerogatives of the Reich President and independence of town halls", as well as "guarantees for clerks who were members of the German Centre Party"15. It was also agreed that those agreements would be represented in writing. Nevertheless, when

Reichstag reassembled on $23^{\text {th }}$ March there was still no written contract, but the leader of the German Centre Party was assured that it would have been presented by the time of vote. That did not happen. The Nazis' behaviour was not a good sign. Hitler did not turn up wearing a black suit [...], but a brown shirt, and the building was cordoned off by SS units. The SS units lined up inside in a row greeting the deputies with chanting: "Bill on unlimited authority or beating". ${ }^{16}$

The session was Hitler's success. According to the bill, which was entitled innocently Of abolishing misery of the nation and the Reich, creating concentration camps, using searches and forfeiture of property to the state were deemed possible and legal as fixed elements of a system of repression. The new regulations meant an actual liquidation of freedom of speech and assembly (cf. Bethge, p. 40). A nightmare of the rule of terror and Neopaganism, which Bonhoeffer and people like him tried to prevent, in front of them was changed into reality.

\footnotetext{
${ }^{11}$ Cf. M. Steinert, op. cit., p. 200.

${ }^{12}$ Ibidem, p. 204.

${ }^{13}$ Cf. ibidem, p. 203.

${ }^{14}$ Cf. ibidem, p. 208.

${ }^{15}$ Ibidem.

${ }^{16}$ Ibidem.
} 
Christians in Germany faced the question how should they treat a new government and changes in the way the state machine worked. Circles of evangelicals, that is the majority of German worshipers were in an especially difficult situation - "the total burden of social, national and theological conditions of the Evangelical Church pressed towards loyalty, even at the big cost, and many people, who did not disregard these costs, thought that it was correct" (Morawska, p. 55). People who thought in a similar way as Bonhoeffer or Barth were a minority. Obedience of the church structures to the legal authorities was after all innately connoted with the idea of Reformation, resulting from inscribed in Lutheranism division of the "kingdoms", that is the spiritual and secular world (cf. Morawska, p. 56-60).

The Nazis cleverly made use of religious slogans to attract the biggest social groups. The course of events showed that the impossible became possible - ideas and slogans which were completely inconsistent with the spirit of the Gospel were absorber and brought into action by people who thought themselves as excellent Christians. What is more, the elements of the Christian world view, especially limited for Nazi needs, were used for explaining the actions contradictory with any ethical system. The efficacy of Hitler's and his circle tactics, which were supposed to make the impression that the Nazis felt deep and true respect for Christian values, let be shown by an excerpt of the letter written by one of the minister, which Morawska and Bethge quoted:

I was not supposed to as Parish priest to be involve politically in a party. However, then NSDAP got into power, which did not want to be a party with manifesto, moral and religious principles. Then, I became a member of this movement. There was another reason. It was clear that lower bodies of this movement might not be imbued with deep morality and religiousness of führer and his idea, that $[\ldots]$ various heretics deprived of conscience would use this movement to their own purposes, in order to get into influential positions. [...] As a result obstacles in preaching the Gospel could happen and thereby would be lost the only foundation, which the restoration of the homeland could be made on, for the sake of Christ Church and the nation. Therefore, I wanted to collaborate with NSDAP in order to prevent it. ${ }^{17}$

A year before Hitler's rise to power the movement known as Deutsche Christen was established, which was an organization consisting of the most confirmed followers of the Nazi party inside the church structures. In 1933, the so-called Kirchenkampf flared up - power struggles in a Church uniting in the name of a new power. Then, two arguments started fighting each other, two ways of thinking about the Church - state relations.

\footnotetext{
${ }^{17}$ As cited in: Morawska, p. 59.
} 


\section{German Christians did everything to}

Spread in Church the principles and orders of the Third Reich, as Führerprinzip and Aryan article. They also worked out a unique theological version of Nazism. They wanted, among others, to finish with the Old Testament, "that distasteful history of Jewish cattle traders", and create supradenominational German "positive Christianity". [...] In that new form of "revelation" the cross was a symbol of what was necessary to sacrifice in the name of the Reich. Swastika was a cross combined with hope shown by Hitler (Morawska, p. 60).

Opposed to Deutsche Christen were people of Barth and Bonhoeffer's sort and all who the nationalist ideology voiced by NSDAP treated as a threat for the Church's mission. Many people did not agree with the "heresy" and coarse "natural theology" of German Christians. Some who thought that way were. However. a minority and their voice was drowned by the servile exclamations cheered in honour of the commander.

Eventually, on $23^{\text {th }}$ July 1933 , Deutsche Christen won the elections to the Reich Church authorities. Ludwig Müller took the lead of it in August and from then on he was addressed an archbishop, who tried to put church circles in "order" similarly to the one imposed in the whole country by NSDAP.

Those difficult months were for Bonhoeffer a time of intensive activity. $\mathrm{He}$ mulled over and gave the opposition ministers different ideas on striking forms - funeral strike, resignation from the Reich Church, which he regarded as heretic. He also edited the first version of the Protestant "confession", which was supposed to specify the principles of faith under new conditions. That text was called the Confession from Bethel. When in autumn Berlin synod decided to support the Aryan article in Church, that is for depriving all the ministers with Jewish origins of office and forming by baptised Jews a different church organisation, Bonhoeffer wrote in a special protest leaflet that "expelling Christians-Jews from the community [...] destroyed the substance of Church itself " $"$. Because of that - he proved -

In relation to the Church, which introduces - in this radical form - Aryan article, only one way of serving the truth is possible: withdrawal. It is a final act of solidarity with my Church, which I cannot serve in other way than in truth, the whole truth and all its consequences. ${ }^{19}$

Tortured by doubts on his further path, discouraged by a lack of response, which he demanded from the Church side, he made a decision to leave for Lon-

\footnotetext{
${ }^{18}$ D. Bonhoeffer, Wybór pism, p. 68.

${ }^{19}$ Ibidem, p. 70.
} 
don, where he had a German parish to assume. In the letter to Barth he explained the reasons of his act as follows:

I felt that in a strange way I had found myself in a radical opposition to all my friends. I was falling in bigger and bigger isolation in my views, although I preserved close relations with all those people. Everything filled me with fear, I lost self-confidence, I was afraid that I would finally break my neck because of my fight for what was right. [...] Thus, I was thinking about going for some time to "desert", or just doing the parish work, by all means unpretentious. Any big gesture seems to be more dangerous than stepping aside. Isolation. It has happened..$^{20}$

The response of the professor was harsh and unambiguous: Bonhoeffer should come back to Germany as quick as possible, where he is needed - "we are not allowed now to play with Elijah under [bush of juniper], nor Jonas under [cestorbean], but we should shoot from all the barrels"21! Yielding to our own weaknesses - Barth argued - consisting in evading certain "decisions", is much more harmful than being mistaken in a concrete action. "The House of the Lord Church is burning, [...] you should come back in the nearest boat [...] Let us say in the last resort: the second in a row"22.

He returned a few months later. In the Reich there existed then a Confessing Church (Bekennende Kirche), that was an Alliance of church forces, which had courage and strength to stand up to the domination of German Christians. During a well-known synod in Barmen (May 1934) the views of Deutsche Christen were condemned and unanimously acknowledged as heresy: "We reject false teachings, Church with God's word supposedly could and had to recognize as a source of its Annunciation any other events, forces, figures and truths as God's Revelation"23. Still during his stay in Great Britain Bonhoeffer sent to the German state and church authorities numerous protests against destroying Church independence, also starting insistent efforts for Bekennende Kirche to be recognized for ecumenical circles as giving at the same time his critical opinion about Deutsche Christen to these international bodies do Deutsche Christen. In a conference organised by the World Alliance of International Friendship Through Churches in Fanö he incited to formulate through "great ecumenical council" the message of peace for the world, which:

despite dislike $[\ldots]$ will have to accept the word of peace, and nations will gladden, it is a Christ Church which will take the gun from their hands and forbid the war, and

${ }^{20}$ Ibidem, p. 80 .

${ }^{21}$ Ibidem, p. 82. See also: Bethge, pp. 44-45 (I have also used the translation of Barth's letter included there).

${ }^{22}$ D. Bonhoeffer, Wybór pism, p. 83.

${ }^{23}$ As cited in: Bethge, p. 46. 
will announce Christ peace over the raging world... Time is passing - the world is arming... even tomorrow military fanfares can resound - what are we waiting for? Would we like to become accomplices as never before? ${ }^{24}$

In the months preceding his return to the country Bonhoeffer was preparing his departure to India. His friends received for him even personal invitation from Gandhi. As it seems, he wanted to explore the mechanisms of exerting a peaceful pressure on unfair authorities, manifesting social disagreement. Nevertheless, the trip did not come to effect. After the council in Dahlem established church structure of Bekennende Kirche independent from Church of Reich, the author of Act and Being was called to come back to the country. He was about to assume a position of lecturer in a semi-legal preacher's seminary.

That period of Bonhoeffer's life is known first of all as time of functioning "evangelical monastic fraternity" 25 , which the seminary for the preachers in Finkenwalde ran by the Berliner theologist changed into ${ }^{26}$. As fr. Andrzej Napiórkowski noticed, a form of community life for the seminarians proposed by Bonhoeffer was within the confines of Protestant a religiousness "novum, similar to sect style or - what was worse - Catholic monasteries, which in the Lutheran tradition were associated inevitably with emphasizing the human input in achieving salvation with a simultaneous depreciation of his absolute gratuitousness which was obtained by Christ" 27 . The fruit of those years of intensive work were also two important books, Life Together and Disciplineship.

In 1936, their author was banned from lecturing at the university. A dozen or so months later gestapo liquidated the seminary in Finkenwalde.

In the meantime in Confessing Church a dissonance was becoming evident between the ones who - as Bonhoeffer - did not want to make concessions towards the authorities and a considerably numerous group of hesitating and not infrequently prone to capitulation. After announcing criminal Nuremberg Laws, aimed against "non-Aryans", an interpellation to Hitler was made, which publication in the papers of "Morning Post" stirred up a storm in Germany, in 1937 a protest on liberating the members of Bekennende Kirche who had been arrested - then there was a breaking in "police cordon, which surrounded the church during the service for the arrested" and "march along Berlin streets" (Morawska, p. 74), but there was

\footnotetext{
${ }^{24}$ As cited in: Bethge, p. 49.

25 A. Napiórkowski OSPPE, Wstęp, in: D. Bonhoeffer, Życie wspólne, transl. K. Wójtowicz, Wydawnictwo Alleluja, Cracow 2001, p. 10.

26 Today Finkenwalde is named Zdroje and is one of the districts of Szczecin. In 2000, the Saint Trinity parish of the Evangelical Church of the Augsburg Confession took over the lands of the former seminary, and three years later at the Piotra Skargi Street there was founded the Dietrich Bonhoeffer International Centre of Studies and Meetings

27 A. Napiórkowski OSPPE, op. cit., p. 24.
} 
not an unanimity within church circles - cunning operations carried out by the authorities, which were supposed to lead to the internal split and terror resulted to be successful ${ }^{28}$. The publication of Karl Barth's letter, who was unambiguously known because of Bekennende Kirche, added fuel to the flame. Commenting on the military plans of the Reich towards Czechoslovakia, he wrote from Basel to one of the Czech professors: "Each Czech soldier, who will fight there and suffer, will suffer and fight for us and [...] the Church of Jesus". This church, according to Barth, "within the orbit of Hitler and Mussolini", could only become "ridiculed, or be annihilated "29. Those words were commonly considered as treason.

Bonhoeffer kept on being involved in church education, but underground initiatives had been already present. In the Confessing Church his uncompromising attitude met with an increasing lack of understanding. The author of Disciplineship observed with growing criticism the actions of his brethren, arguing with public authorities about important - but rather not concerning Christian ethics - legal-administrative issues. He was terrified by the lack of proper, strong enough response of the Church to the progress of the Nazi totalitarianism. In March 1939, he wrote to his English friend, George Bell, Bishop of Chichester, that he considered leaving Germany. He wondered whether during emigration he could serve better the issue of faith. One of the reasons of those dilemmas was a threat of being called up to Nazi army - mobilization of the generation 1906 was about to come.

His friends from the USA did everything to convince him to leave. They managed to achieve some success. In June, three month before the war broke out, Bonhoeffer turned up in the USA. That American episode Anna Morawska called "the most surprising event in [his] life" (Morawska, p. 120). Why? His friends hoped he would stay there for good. They treated their measures as a rescue operation the position of chaplain of German immigrants waited for Bonhoeffer. However, the result was that the author of Life Together found Karl Barth's lesson given several years earlier memorable - one month later he was sitting on-board a ship sailing to Europe. In the letter to Reinhold Niebuhr he justified his decision as follows:

I made a mistake in coming to America. I must live through this difficult period in our national history with the people of Germany. I will have no right to participate in the reconstruction of Christian life in Germany after the war if I do not share the trials of this time with my people... Christians in Germany will have to face the terrible alternative of either willing the defeat of their nation in order that Christian civilization may survive or willing the victory of their nation and thereby destroying civilization.

${ }^{28}$ It is worth mentioning the praiseworthy initiative of Bekennende Kirche, which in autumn 1938 ordered to hold in parishes a special service connected with_confessing the guilt of the Church and the nation, as with pray for the peace. One of the SS newspapers called the actions made by the Church "treacherous deeds in a spiritual form". Cf. Morawska, p. 76 and Bethge, p. 61.

${ }^{29}$ As cited in: Morawska, p. 76. 
I know which of these alternatives I must choose but I cannot make that choice from security. (transl. Geoffrey B. Kelly) ${ }^{30}$

Bonhoeffer's choice of the Christian civilization led directly to his involvement in the underground. The atmosphere of his family house was important as well, where in the 1930s people speaking against Hitler used to meet. As far back as in 1938 Bonhoeffer knew about initiatives carried out by a group of people connected with Abwehr aiming at overthrowing the Nazis. To that group formed by among others Beck, Goerdeler, Canaris and Oster, belonged also the minister's brother-in-law, Hans von Dohnanyi, a clerk in the Ministry of Justice.

The first attempt leading to a coup d'état was made after dismissing Werner von Fritsch as Commander in Chief of the German army. A large group of military men was then ready to stand against the government. If intentions of the conspirators had been put into actions, probably the war would have never been possible.

Another plan for overthrowing Hitler was prepared carefully:

In case of the order to attack Czechoslovakia, it was to demand Himmler's and Heydrich dismissal, and as it was supposed, Hitler had refused, take over Gestapo headquarters, arrest them both, and then encircle Reich Chancellery and present Hitler with a fait accompli. It was planned to remove him on the basis of the insanity plea, which Karl Bonhoeffer had already worked out, then the most outstanding psychiatrist in w Berlin (Morawska, p. 148-149).

As it is known, the assault to Czechoslovakia did not come into effect - leaders of European countries "saved the peace" in Munich, giving Hitler the Sudety Mountains $^{31}$. Conspirators had to wait for another favourable situation ${ }^{32}$. In the

\footnotetext{
${ }^{30}$ As cited in: Morawska, p. 123.

${ }^{31}$ It is worth remembering that it was not the only ultimatum given to Prague on that day. The Polish government demanded a part of Cieszyn Silesia. Left by everybody Czechoslovakia met this demand too.

${ }^{32}$ Amongst the body of generals and in the circles of the military intelligence a few more plans of coup d'état arose. All of them were enumerated and discussed by Anna Morawska. First of them was created just after the outbreak of the Second World War. Many people were terrified with information about the operations of the German army and SS in the lands of the eastern neighbour. "General Blaskowitz, commander in chief in Poland, wrote in protest addressed to Hitler that everything which was said about it by the enemy western radio stations, is nothing compared to the reality" (Morawska, p. 150). There could have been only one reaction to such protest - instantaneous general's dismissal. The negotiations were carried out between Vatican and London about the terms of peace treaty after Hitler's overthrow. One of the generals offered even to arrest führer during inspection, which he was supposed to carry out in military units of the Army of Rhine. However, that inspection never happened. Another attempt of thwarting military plans and bringing about to coup d'état was made informing the Dutch about an attack on their country which had been planned by the German Army (Oster passed this message on). It was, as Bonhoef-
} 
meantime behinds Hitler's back they carried out negotiations with the West. They did not get any results.

Bonhoeffer was employed as a civil co-worker of Abwehr in October 1940. Nobody knew that in reality he was involved in conspiracy actions. Within the confines of his duties he made several journeys, in which he gathered information and passed on "information on the German Resistance actions" abroad (Bethge, p. 66). At the end of 1941 he co-organized a transfer of a group of Jews to Switzerland. In May of the following year he passed on precise information about a coup being planned to Bishop Bell including the list of people responsible for it. It aimed at helping the Allies to find their bearings with complicated interior situation of the Third Reich and enable to entrust future government to the right people in Germany.

Soon after Bonhoeffer and von Dohnanyi were under observation of Gestapo, their phones were tapped. On $5^{\text {th }}$ April 1943 the author of Disciplineship was arrested.

At the beginning danger did not seem to be high. It turned out that Gestapo had not yet managed to work out the conspiracy group. Testimonies given by consul Schmidhuber from Munich Abwehr unit included only vestigial information about handling documents and dispatching people of Jewish origin abroad. The investigation was in progress, Bonhoeffer had to prepare a strategy of giving testimonies.

Bonhoeffer spent more than four hundred and fifty days in the military prison Tegel in Berlin. As Bethge wrote, life there was "a torment at the beginning" (Bethge, p. 76). Although two other arrestees in that case-Hans von Dohnanyi and Josef Müller - were held in different places, Bonhoeffer could check on the progress of the police investigation thanks to illegal correspondence with his relatives. After some time, when the first questioning finished, the "cell [...] changed into study room" (Bethge, p. 76). The minister with charming manners promptly won over sympathy of the guards, and when it resulted that the general Paul von Hase, Commander of the capital city, was his uncle, he gained special considerations ${ }^{33}$.

fer's biographer noticed rightly, "an unbelievable deed because of the German tradition and good manners, as [...] common human ethics in general" (Morawska, p. 152). With the time passing Hitler was gaining enemies. In 1942, an assassination attempt was plotted - the political system of future Germany was being prepared, it was established who would take the power after führer's death, negotiations on the terms of capitulation with Allies were carried out, etc. In 1943, in a plane with the Third Reich leader there was hidden a time bomb which had the shape of "a parcel with two bottles of brandy". Nevertheless, the charge did not explode. The plans of general Rudolf von Gersdorff, who was going to make a suicide bombing on Hitler's life came to nothing. There were three attempts of slaying führer in July 1944. Each of them failed. Afterwards, there was a wave of arrests and any further actions of the conspirators resulted to be impossible.

${ }^{33}$ Bethge wrote even that "prison officials [...] treated Bonhoeffer as if he had been a film star" (Bethge, p. 77). Another thing is that he replied to it with one word: "Pity!" - he saw no reason to be 
During his stay in Tegel Bonhoeffer continued a regular correspondence with his friend Eberhard Bethge, former seminarian in Finkenwalde, who then was doing military service ${ }^{34}$. A part of those letters was acknowledged after the war as work determining "beginning of the new theological era" (Bethge, p. 80), author of Life Together formulated there an idea of "Christianity without religion", which after years gained many advocates throughout the Christian world. It resulted that the theologian and cregryman, involved in complicated underground actions, observing at close range the progress of the criminal system, was able to describe properly the conduct of the contemporary believer, a Christian in the century of totalitarianisms.

The most important question which was asked in the famous Letters from prison, published after the war by Bethge, was a question about the place of Christ in the contemporary world. It was connected with the reflection on human condition, who has to live as if God did not exist, agreeing to "impious" reality.

The best known, the first of the series of "theological letters", written on $30^{\text {th }}$ April 1944, included the following diagnosis of the contemporary religion and religiosity:

The time of religion has already passed. We are going forward the time completely nonreligious $[\ldots]$ "Christianity" has always been a form of religion (probably a real one). However, if it resulted one day that this a priori did not exist, but it had been a determined by time and a form of human expression which has been going by, if the people indeed would become radically nonreligious- I think that to a lesser or bigger extent it is a fact (which consists in for instance that current war, as distinct from all of those up to now, does not cause any "religious" reactions?) - what will it mean for "Christianity"? [...] If religion is only a robe of Christianity - and this robe in different times looks in a different way - so, what is a nonreligious Christianity? ${ }^{35}$

Bonhoeffer was not meant to find the answers. However, his notes survived in the letters were enough to - as James Mark phrased it - give "us the most significant and fruitful insight in our times" ${ }^{36}$. The author of those notes did not survive the war.

treated in a different way than others. "After twelve days one knew about my family connections. As a matter of fact, it was a convenience for me but objectively it made me ashamed that in one moment everything could change. I was moved to a more spacious cell, which was cleaned every day by a cleaning lady, during meals I was given bigger food rations I did not want to take because it happened at the expense of other prisoners, the governor took me for daily walks and as a result all the Staff started to turn to me with a sophisticated politeness" (as cited in: Bethge, p. 77) - in one of his letters.

${ }^{34}$ Despite everyday prison activities, he took care of the ill and organising the protection during the Allies air raids, did the reading and writing. Those prayers written especially for the prisoners, as well as a poem collection, excerpt of a drama and sketch notes of the novel being written originated from that period.

${ }^{35}$ D. Bonhoeffer, Wybór pism, pp. 239-240.

${ }^{36}$ As cited in: Bethge, p. 129. 
On $20^{\text {th }}$ June Stauffenberg made in Wolfsschanze an attempt on Hitler's life. Under the table with maps, at which among others Hitler and Keitel were standing, the bomb exploded. It seemed to be impossible that the dictator could survive the explosion. Stauffenberg reached Berlin, where the "Operation Valkyrie" begun, which was to lead to overthrowing the Nazis ${ }^{37}$.

Nevertheless, Hitler did not die. Having arrested people responsible for the June assassination attempt and finding in Zossen Dohnanyi's archives details of underground actions carried out from 1938, the worst could come in any moment. For some time Bonhoeffer was even preparing himself to run away from Tegel (he was supposed to get out with the help of one of the guards, disguised as a fitter). Finally he gave up those plans when his relatives were arrested - he did not want to worsen their situation.

On $8^{\text {th }}$ November he was moved to the Prinz-Albrecht-Straße prison, which was situated in the cellars of the Reich Main Security Office. Interrogations resumed. Investigating officers wanted to know all the details of international abwehr missions.

At the beginning of February, with a group of other prisoners Bonhoeffer was taken to Buchenwald, and from there to Regensburg and Schönberg. On $9^{\text {th }}$ April in the camp of Flossenburg the participants of conspiracy against Hitler's life were executed. Bonhoeffer, Oster, Canaris and a few others were hung. Thirty days later Germany signed the Instrument of Surrender.

\section{Różewicz}

In the seventh issue of "Evangelical Herald" from 2005 one can read as follows:

On Saturday $19^{\text {th }}$ March this year a session of the Synod of the Wroclaw Diocese Evangelical Church of the Augsburg Confession started with confessional-communion service in the Evangelical church of God's Providence in Wroclaw. [...]

${ }^{37}$ A message about Hitler's death soon came also to the lands occupied by the Nazis. Tadeusz Różewicz thus recollected that time: "I was in the city 'on the leave' from my troop... [...] during this 'leave' found out about the_attack on $20^{\text {th }}$ June to Hitler... first news that Hitler died... [...] I was going alone along a burning June street and I was thinking: 'It is the end of the war'. End of the war and obviously Germany must release all of the prisoners. Janusz is saved. [Janusz, pseudonym. "Gustaw", "Zbyszek", older brother of Tadeusz Różewicz, was then, as Bonhoeffer, a prisoner of gestapo. He was arrested in Łódź for collaboration with Polish intelligence. On $10^{\text {th }}$ November 1944 he was executed.] And then at the street I started praying ... end of the war... prisoners free. Janusz free - and then praying to God, saying a thanksgiving prayer I though mad - that the attack of $20^{\text {th }}$ June and Hitler's death are God's intervention in the history of the world and Janusz's life... it seemed to me that God changed the face of the world and run of the events to save millions and my Older Brother" (NSB 148). 
During the Synod the new year's issue of “Diocesan Year's Issue", including despite current reports of environmental priesthoods, richly illustrated reports from the most important events, which took place in the parishes belonging to this diocese in 2004. It is interesting that specially for the readers of "Diocesan Year's Issue", Tadeusz Różewicz dedicated one of his unpublished poems. The poem is entitled Learning to walk and was inspired by the person of Dietrich Bonhoeffer, evangelical theologist and an activist of anti-Nazi opposition born in Wroclaw, and his work. ${ }^{38}$

Learning to walk opened "Diocesan Year's Issue". It was only preceded by a title page and an editorial page, table of contents and a registry of synod participants. At the top of page five there was a heading: "Poem by Tadeusz Różewicz dedicated to the readers of 'Diocesan Year's Issue"'. Below the text of learning to walk there was a monochrome photograph. It showed the author of Exit standing in front of the Wroclaw monument of Bonhoeffer. Whoever took it, must have been standing in one of the windows in the tenement "Hansel" overlooking the square near the Garrison church. It might have been Eugeniusz Get-Stankiewicz.

Contrary to the information included in the quoted report from the synod session, the poem had been previously published in the press ${ }^{39}$. Probably also information about the dedication to the readers of the diocesan periodical was announced too rashly. As a matter of fact, Tadeusz Różewicz passed on the text of learning to walk to Zbigniew Kulik - custodian of the parish Wang and director of the Sport and Tourism Museum in Karpacz - but the only desire, which he expressed then, concerned the possibility of showing the work to the readers of Evangelican Church of the Augsburg confession. A different thing altogether is that the choice fell on Wroclaw "Diocesan Year's Issue".

What did persuade Tadeusz Różewicz to publish learning to walk in two magazines - in the first place in "The Catholic Weekly", then in the Evangelical "Diocesan Year's Issue"? The intention of the poet was, as it seems, to show (remind) the readers the person of Dietrich Bonhoeffer, a contemporary martyr and an outstanding theologist, whose unfinished work remains probably one of the most authentic witnesses of the faith of the contemporary human. A sign of uniqueness of this poem in Różewicz creative output, making a turning point, is not only its central place, which it takes in the collection Exit (it is preceded and followed by twenty one poems), but above all its content - showing new direction to poetry, which sets new tasks.

Here, in an imaginary conversation between Różewicz and Bonhoeffer a demand of a new beginning was formulated. After a few decades of writing poetry

\footnotetext{
38 Wiosenna sesja Synodu Diecezji Wrocławskiej, „Zwiastun Ewangelicki” 2005, issue 7, p. 19.

39 T. Różewicz, nauka chodzenia, ,Tygodnik Powszechny” 2004, issue 22, p. 13.
} 
the author of Lament, in which there was a well-known phrase of the Christian credo ${ }^{40}$ inversion:

$\begin{array}{ll}\text { "Nie wierzę w przemianę wody } & \text { [“I do not believe in the changing of } \\ \text { w wino } & \text { water into wine } \\ \text { nie wierzę w grzechów odpuszczenie } & \text { I do not believe in remission of sins } \\ \text { nie wierzę w ciała zmartwychwstanie" } & \text { I do not believe in the resurrection of } \\ \text { the body"] }\end{array}$

he wrote:

$\begin{array}{ll}\text { Bonhoeffera spotkałem we Wrocławiu } & \text { [Bonhoeffer I met in Wroclaw } \\ \text { zacznij od początku } & \text { start from the beginning } \\ \text { zacznij jeszcze raz mówił do mnie } & \text { start again he would say to me } \\ \text { naukę chodzenia } & \text { learn to walk } \\ \text { naukę pisania czytania } & \text { learn to write to read } \\ \text { myślenia } & \text { to think] }\end{array}$

(transl. Bill Johnston)

As a key link of Różewicz's book, source of meanings written in that complicated poetic structure, learning to walk makes also a peculiar point of reach and - exit, self-portrait of the poet who is still ready for the new, does not evade seeking the truth even at the cost of reformulating his own seemingly unalterable vision of man and the world. Lessons of "walking", which Dietrich Bonhoeffer gave to the author of Low relief, are lessons in humility, giving oneself up, abandoning views and opinions, which, as it seems, do not accede to the real image of what is.

The response to the question on the source of that apparently unusual and unexpected community of thought should be found in the most important generation experience of Bonhoeffer and Różewicz, which was the war. When it broke out, Bonhoeffer was 33 and he had been involved in the German church opposition against official Church of Reich for a long time, the eighteen-yearold Różewicz had just passed the entrance exam to the forest high school and was preparing for a trip to Radomsko: "Suitcase was packed. On the last day of August I was supposed to go to Żyrowice near to Słonim, to become a brave forest officer" ${ }^{\prime \prime 1}$.

\footnotetext{
${ }^{40}$ Cf. A. Fiut, Po śmierci Boga (O twórczości Tadeusza Różewicza), “Teksty Drugie” 1993, issue 3.

${ }^{41}$ From a letter to Kazimierz Wyka. As cited in: Z. Majchrowski, Różewicz, Wydawnictwo Dolnośląskie, Wroclaw 2002, p. 58.
} 
Before the war Różewicz published his poems in journals such as "Under sign of Mary" and "Red Shields" " "My first poem was published in a journal of Sodality of Our Lady, its sources were metaphysical" - he said in a conversation with Krystyna Nastulanka (WS 19). The "Under sign of Mary" monthly, the authors and readers of which were first of all members of the Marian religious brotherhood, had been appearing in Zakopane from $1921 \mathrm{roku}^{43}$. For two years before the war the teenage poet published in its papers seven poems on religious matters.

In the context of subsequent works of Różewicz specially worth mentioning is a poem entitled Empty church. God hidden in Blessed Sacrament seems to be separated from the world with an impenetrable barrier, in a deserted interior of the church it appears as an "Orphan" - abandoned by people, "separated from outside reality" ${ }^{\prime 4}$ :

Samotny Chrystus
zamknięty w złocistym kielichu
$[\ldots]$
lampka czerwona płonie
(nie ma skarg i modlitw błagalnych)
jest tylko światło
obrazy i złoto. ${ }^{45}$

[Lonely Christ closed in a golden chalice $[\ldots]$ the red lamp is shining (there are no complains and supplicatory prayers) there is only light paintings and gold.]

In the attitude of the lyrical subject Tadeusz Kłak noticed "distance and a kind of indifference to transcendent reality" - "emptiness [...] of the [church] interior can be interpreted also as emptiness in a religious and spiritual sense" ${ }^{946}$. If that interpretation was recognized as correct, that juvenile poem should had be acknowledged as an anticipation of post-war views of the author of Anxiety on religion and metaphysics, or rather as evidence of the process of leaving the religiousness which started early ${ }^{47}$ - however until the experience of war became for Różewicz a boundary situation, which changed completely the way of perceiving the world and $\operatorname{man}^{48}$ :

\footnotetext{
${ }^{42}$ Cf. T. Drewnowski, Walka o oddech. Bio-poetyka. O pisarstwie Tadeusza Różewicza, Wydawnictwo Literackie, Cracow 2002, pp. 41-42.

${ }^{43}$ T. Kłak, Liryka Sodalisa. O juweniliach poetyckich Tadeusza Różewicza, in: idem, Spojrzenia. Szkice o poezji Tadeusza Różewicza, Biblioteka Śląska, Katowice 1999, p. 66. I derive all the information about youthful poems of Różewicz from this study.

${ }^{44}$ Ibidem, p. 71.

${ }^{45}$ Ibidem.

${ }^{46}$ Ibidem, p. 72.

${ }^{47}$ In this way Tadeusz Kłak perceives it (ibidem, p. 73)

${ }^{48}$ As rightly Andrzej Skrendo notices (Tadeusz Różewicz i granice literatury. Poetyka i etyka transgresji, Universitas, Cracow 2002, p. 265), war is "in Różewicz work a paradigm of any trans-
} 
Baptism. Holy Communion. I took God. I deeply believed it. I was taught religious education by Miss Kryszczyńska in Radomsko. I was her favourite pupil, teacher's pet. She prepared us to Holy Communion, the whole class, forty pupils. Majority of my peers, me for sure, We took God indeed. This wafer on the tongue... one turned eyes... one knelt for a moment... Then we got up... And one was going away with Christ inside oneself... In order to kneel somewhere in a silence... It was an experience of a child who then come back to an old dying man. However meanwhile something died... [...] other experiences came. Those were which caused devastation (JT 180).

Describing his state of awareness after the war, Różewicz used the image of ruins of the St. Mary's Basilica in Cracow. As he admitted, he was writing then a poem about that building. The idea of poem: "...passers-by think that, St. Mary's Basilica has not been harmed but they do not see that there is a huge pile of bricks and stones. The church lies in ruins. The church has been destroyed in my inner feelings. This building, which they look at, is not a church, monument of architecture, piece of art, it is a ravages, bust shed, a pile of debris ..." (PR III 143). The aspiration to reconstruct the church, raise "this church inside of ourselves", and as a result - "reconstructing man" was equivalent to an attempt of cancelling what was inherited by the humankind because of the war, which "deprived us of unity with the revelation"49. The author of Low relief never finished that poem. A return to the state of awareness preceding the catastrophe was not possible for him - a Gothic cathedral inside of him became rubble.

The poetry of Różewicz from the first decades after WWII was a moving evidence of apostasy. It was not out of the question that for some time the poet was driven to "ontological atheism" 50 . Then, in his work there occurred a final - as it might seem - alienation from faith: "in poetry I cut myself from metaphysics, mysticism; I cut myself from certain matters, it was an operation more difficult that cutting myself from 'poetics', od rhyme, etc. I became unambiguous" (PR III 249).

However longing for the state preceding the apocalypse, when the world appeared to be a coherent unity, which particular elements occupied their proper places, which is destined only for them, when:

gresive experience, $[\ldots]$ because it moves the subjuct whis experiences it beyond any borders. It takes place on the other side of the line, so it is not only increased by the experience of the border but it also drives the category of experience to its limits".

${ }^{49}$ Expression by Dietrich Bonhoeffer. As cited in: Bethge, p. 34.

50 This term was coined by Jerzy Nowosielski, a painter and the poet's friend, who in the conversation with Zbigniew Podgórzec said: "Just as alive is an experience of God as a burning bush, in the same way alive can be the feeling of non-existence of God. It happens very rarely, it is something very releasing, bordering on euphoria. [...] However, it can happen only at a very young age, when a man has a whole life ahead and his feelings are very vivid..." (Z. Podgórzec, Mój Chrystus. Rozmowy z Jerzym Nowosielskim, Wydawnictwo Luk, Białystok 1993, pp. 63-64). 


$\begin{array}{ll}\text { „las był lasem } & \text { [“forest was a forest } \\ \text { Bóg Bogiem } & \text { God was God } \\ \text { Diabeł Diabłem } & \text { Devil was a Devil } \\ \text { jabłko jabłkiem } & \text { apple was an apple } \\ \text { łąka łąką } & \text { meadow was a meadow } \\ \text { góra górą } & \text { mountain was a mountain } \\ \text { dolina doliną } & \text { valley was a valley } \\ \text { prawda prawdą } & \text { truth was truth } \\ \text { drzewo drzewem } & \text { tree was a tree } \\ \text { kłamstwo kłamstwem }[. . .] & \text { lie was a lie } \\ \text { śmierć śmiercią } & \text { death was death } \\ \text { życie życiem” } & \text { life was life”] }\end{array}$

(Acheron at twelve noon, P II 312),

time after time was in this poetry to become prominent. Ryszard Przybylski was not mistaken, when in a perceptive review of the collection of poems entitled Regio he stated that:

Różewicz found himself on the way to Emmaus. [...] in a few days after a horrible pogrom, just after Christ's death, he left oppressed with Eliot from the City, where the world's salvation was made. Going along a dusty white way all the time he was explaining to Eliot that faith is pointless. This dialogue of the Great Apostate and the Great Christian lasted a dozen or so years. ${ }^{51}$

In a New Testament story, Cleopas and Simon, Jesus's disciples, went from Jerusalem to Emmaus. Resurrected Jesus joined them but they did not recognize Him - even when he explained to them the Scripture in details ("But their eyes were kept from recognizing Him" - Luke 24:16) The path of the $20^{\text {th }}$-century poet, who survived the war apocalypse, was "smitten with death", to Emmaus, where Christ broke bread with his disciplines, leads through doubt and pain. But leaving Jerusalem does not mean a final abandonment of God, who became a man; it is rather a path towards the more mature faith, understanding its limitations, a path which leads to the destination, to knowledge which is different than the knowledge of negation. It is because the journey means co-presence of contrasts - leaving and coming, going out and entering. Somewhere at its end the poet is waited upon by an "evangelical saint", a minister Dietrich Bonhoeffer, with his concept of "non-religious Christianity", with cross carried with Christ.

Should the fact that at the beginning of the $21^{\text {st }}$ century Różewicz wrote learning to walk be acknowledged as an unexpected phenomenon, signal of revo-

${ }^{51}$ R. Przybylski, Droga do Emaus, „Odra” 1970, issue 5, p. 126. 
lutionary changes occurring in that poetry? Such an important poem should be rather treated as a continuation of Różewicz's model of thinking about religion and presence/non-presence of God in the contemporary world, as its addition. A vestige of the childhood faith, heedless of all the outer world, trusting in defiance of all and everybody, was saved since in the poet's heart and remained vital, albeit invisible for a long time for readers, point of reference. It was proved by one of the sheets of paper torn from the "Gliwice journal" (notabene, the poet chose to publish those very personal notes almost fifty years after he wrote them):

What is the situation of man who does not believe in God but ... is a non-believer? $\mathrm{He}$ is man who desires faith. Through many years of non-faith I have longed for faith. I have strived for faith. I have had to fast in secret. I strive for it. The only man, in front of whom I had unveiled my sad face, was Mother. Sometimes J... (PR III 337)

Not every atheist is given to desire faith. For all those years when the author of Red glove declared himself as nonbeliever, there was in him - as it seemed - a longing for an original state of this "naive" childlike faith. A return to it would mean agreement to "switching off the light of reason". Therefore, the poet persisted in internal contradiction, showing himself as an apostate (Lament, In a small house, Falling, Thorn, Conversation with a Friend) and longing for faith.

The fact that in the work of Różewicz this need hidden with embarrassment started to become prominent, it became clear from the moment of publishing the collection entitled Regio ${ }^{52}$. Ryszard Przybylski noticed in the "sullen joy and bitter grief, furious triumph and suspect fear" ${ }^{33}$ of a declared atheist a sign of something new, a signal of a focused awaiting. For whom? For Christ, God-Man. As the author of Fight for Breath..., wrote in his "presumptions Przybylski was not isolated. For a long time it had been suspected from various sides in connection with appearing Różewicz output Christian symbolism that he went on the way of Catechumen" 54 . However, for a contemporary poet it is difficult to write about God. Talking directly about matters of faith is not possible. The only way of touching reality, which goes beyond the touchable here and now becomes a contradiction, describing the shortage ${ }^{55}$. God seems as an emptiness after God, the only sign of God's existence is His absence in the human world. Różewicz's attitude was not atheism but rather a way of demonstrating the longing for faith. Writing about a lack of God was regaining him. But:

${ }^{52}$ Cf. R. Przybylski, op. cit.

${ }^{53}$ Ibidem, p. 126.

${ }^{54}$ T. Drewnowski, op. cit., pp. 245-246.

${ }^{55} \mathrm{Cf}$. W. Gutowski, Aluzje biblijne i symbolika religijna w poezji T. Różewicza, in: idem, Wśród szyfrów transcendencji. Szkice o sacrum chrześcijańskim w literaturze polskiej XX wieku, Wydawnictwo UMK, Toruń 1994, p. 140; A. Fiut, op. cit. 


\author{
„najplastyczniejszym [“the most telling \\ opisem chleba description of bread \\ jest opis głodu" is one of hunger"] \\ (Szkic do erotyku współczesnego, P II 351). (Transl. A. Czerniawski)
}

When at the beginning of the 1990s, after a long period of the poet's silence, Low relief was published, numerous literary critics discovered the "metaphysical", "mystical" Różewicz ${ }^{56}$. Poems such as Without, with the famous couplet: "life without god would be impossible / life without god is impossible", ***[Einst hab ich die Muse gefragt...], ***[Expiration of Absolute destroys...] made that issue of "God's leaving" and dying out the religion started to appear as one of the most important - if not the most important ones - in the poetry of Różewicz.

In 1998, editors of the "Znak" monthly turned to the author of Low relief with a request for participating in a survey Christ in the eyes non-Christians. "I cannot comply with Your request," Różewicz wrote in the response, "because Jesus Christ is for me a very important person - he is somebody Close and such GreatDistant that writing about him becomes almost impossible. For me personally the survey concerning Jesus Christ is something unsuitable - even obscene"57. Meanwhile in the poem I saw Him from the collection of poems published in the same year entitled Always the fragment. Recycling "Son of Man" presented to the poet as a homeless man sleeping on a park bench. However, it did not come to the real meeting - the lyrical subject of that poem brushed aside the possibility of having a conversation with Him. Physical distance was in fact cancelled ("pochyliłem się nad nim / i poczułem zepsuty oddech / z jamy / ustnej”, P IV 32; „I leant over him / and I smelt a spoilt breath / from oral cavity), but still there was a barrier of "great embarrassment", shame, fear of the truth ${ }^{58}$ :

\footnotetext{
56 "I have never been [...] a very searching reader of his poetry - Ewa Nawrocka wrote (Mówienie ze środka kleski, „Tytuł” 1992, issue 1, p. 121) - for a moment, I stopped reading him. I went to see his dramas in the theatre from time to time, I omitted prose; I assumed that as a poet he had petered out, I stopped to be interested in it... Perhaps it is the reason why Low Relief astounded me and forced to have respect. [...] I think that the time for Różewicz is to come, and he will be read in a different way than so far; Różewicz, who through reificating description of the world and giving a diagnosis opens with courage and peace to metaphysics of existence deprived of purchase, aware of this severe inconvenience and carrying with dignity its burden. Dorota Heck, analysing the connection between irony and_mysticism in the text Mystical Różewicz (Of notes), she came to a conclusion that "the ironic treatment of the eschatology in w Low Relief does not have to be acknowledged as an objection against spirituality in general. Irony turns into self-irony. 'Me' participates in a drama of mystics who feel that religious statements are transferred into completely arbitrary statement with absolute importance of the same faith” (,Teksty Drugie” 1994, issue 2, p. 148).

57 „Znak” 1998, issue 10, p. 41.

${ }^{58}$ Cf. D. Szczukowski, Tadeusz Różewicz wobec niewyrażalnego, Universitas, Cracow 2008, pp. 245-247.
} 


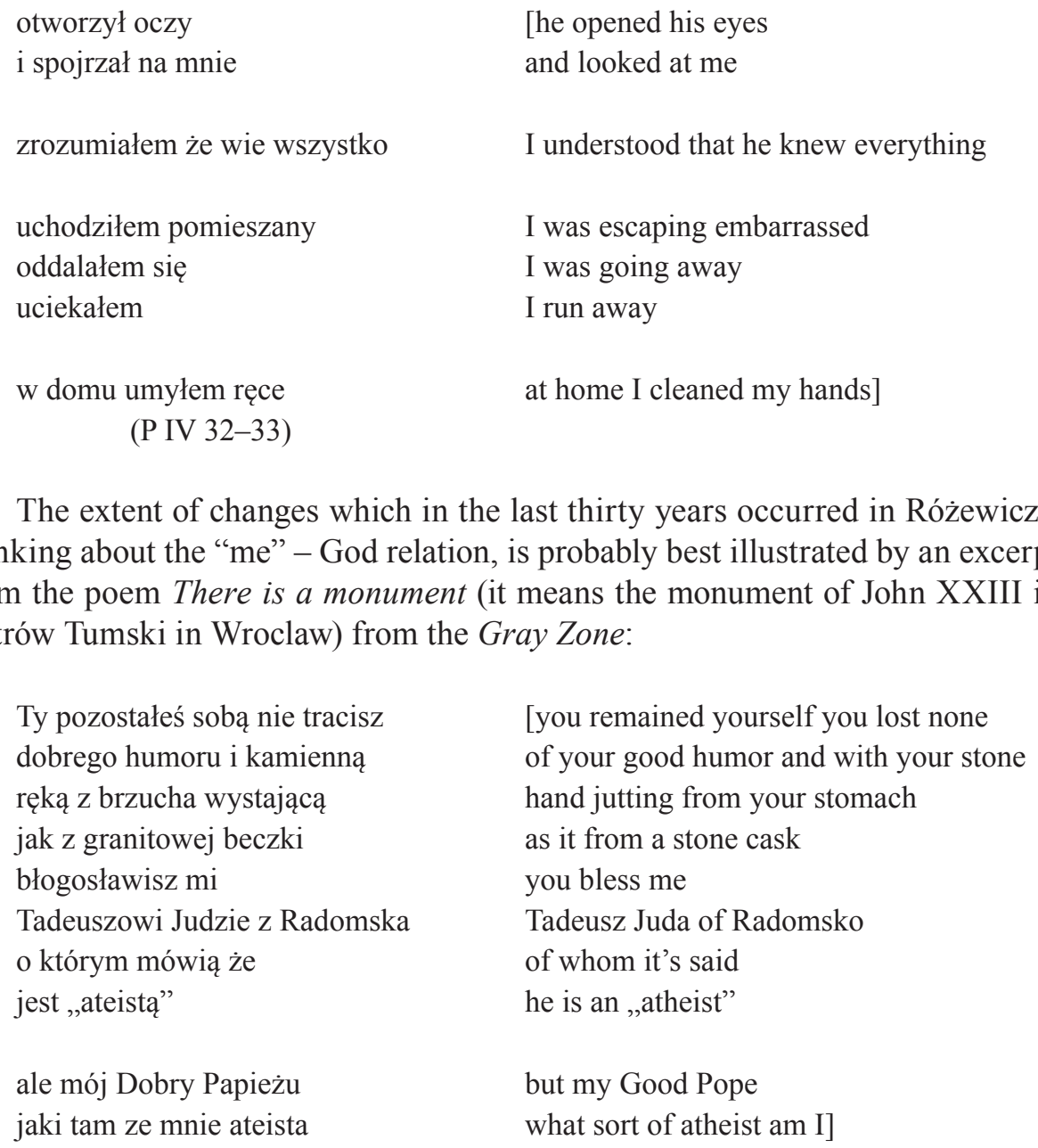

(P IV 148) (Transl. Bill Johnston)

Within more than fifty years of writing, Tadeusz Różewicz went thought a difficult way - from strictly religious poems, published in a religious journal, through poems which were a confirmation of declared by him atheism, to poetry which the main topic is the ability/inability to be a Christian at the beginning of the $21^{\text {st }}$ century, which poses this one fundamental question: "Who is Christ for us?". The journey to Emmaus starts again - from "learning to walk".

Why it was just Bonhoeffer whom the poet chose for the lyrical subject in the most important poem of the collection Exit and a patron of the entire collection? Because theological considerations included in the letters from the prison in Tegel resulted to be for him something like a mirror. The poet noticed his own face in it. He discovered that contemporary forms of Christian religiousness, which he 
could not agree to, against which he protested for the first time in poetry, not uncommonly giving to his readers the reason to call him atheist, can seem to be dead also to a clergyman. In the author of Nachfolge he found views and diagnoses close to his own, especially a conviction that faith is not identical with religiousness, that those two terms often exclude one another.

To understand how much connects the poetry of Różewicz with the theological though of Bonhoeffer, one should compare at least several excerpts of their works.

\begin{tabular}{|c|c|c|}
\hline Bonhoeffer & & Różewicz \\
\hline $\begin{array}{l}\text { Does exist in our Times something like } \\
\text { soul? In the epoch of machines, epoch } \\
\text { of free market economy, domination } \\
\text { of fashion and sport? Isn't it a close to } \\
\text { one's heart memory from the childhood } \\
\text { as many others? In the confusion and } \\
\text { scream of advertising slogans, word } \\
\text { „soul" sounds such wonderfully and } \\
\text { peculiar; it speaks with so quiet and } \\
\text { calm voice that amid gambolings and } \\
\text { noises, we can hardly hear it in our } \\
\text { interior. However it speaks with voice } \\
\text { full of responsibility and deep serious- } \\
\text { ness: you, human, must have soul; heed } \\
\text { not to lose it, having waken up one day } \\
\text { in the run-up of life [...] not to be for- } \\
\text { ced to notice that your interior has been } \\
\text { hallowed-out, that you have become } \\
\text { a toy of events, a leaf in the wind dri- } \\
\text { ven here and there - that here you are } \\
\text { deprived of soul. (Responsibility, transl. } \\
\text { J. Filek, Znak, Cracow } 2001 \text {, pp. 5-6). }\end{array}$ & $\stackrel{\mathscr{\varrho}}{\varrho}$ & $\begin{array}{l}\text { z czego zwłóczy się ciało } \\
\text { z niczego z duszyczki } \\
\text { ćma w nocy } \\
\text { animula } \\
\text { (Duszyczka, P III 131) } \\
\text { [What does the body pulls of } \\
\text { Of nothing of a little soul } \\
\text { Moth at night } \\
\text { Animula] } \\
\text { dusze wędrują } \\
\text { z młodych ciał wychodzą } \\
\text { w grające szafy wchodzą } \\
\text { te dusze niewinne } \\
\text { co grzechu nie znają } \\
\text { nie znają pokuty } \\
\text { [...] } \\
\text { wychodzą z młodych ciał } \\
\text { wchodzą w ciała gwiazd } \\
\text { na wielkich afiszach } \\
\text { [...] } \\
\text { ciała są zawsze niewinne } \\
\text { a dusze coraz mniejsze } \\
\text { tak już malutkie że dwie dusze } \\
\text { mieszczą się na końcu języka } \\
\text { tej portowej dziewki } \\
\text { [souls migrate } \\
\text { leave the young bodies } \\
\text { enter the juke-boxes } \\
\text { those innocent souls }\end{array}$ \\
\hline
\end{tabular}




\begin{tabular}{|c|c|c|}
\hline & $\stackrel{\check{g}}{\varrho}$ & $\begin{array}{l}\text { that don't know sin } \\
\text { don't know penance } \\
{[\ldots]} \\
\text { leave the young bodies } \\
\text { enter the bodies of stars } \\
\text { upon huge posters } \\
{[\ldots]} \\
\text { bodies are always innocent } \\
\text { while souls gradually shrink } \\
\text { now so tiny that a couple } \\
\text { find room on the tip of the tongue } \\
\text { of the quayside whore }] \\
\quad \text { (transl. A. Czerniawski) } \\
\quad \text { (Et in Arcadia ego, P II 250-251) }\end{array}$ \\
\hline $\begin{array}{l}\text { The time passed when it was possible } \\
\text { to tell everybody with words - theolog- } \\
\text { ical or pious - as the time of ,interior } \\
\text { life" and conscience, which means in } \\
\text { general the time of religion. We are go- } \\
\text { ing forward non-religious times; people } \\
\text { who are such as they are now cannot be } \\
\text { religious. Also those who with sincer- } \\
\text { ity call themselves "religious", do not } \\
\text { practice it in any meaning; probably } \\
\text { they understand the term "religious" as } \\
\text { something completely different. (Selec- } \\
\text { tion of works, p. 239) }\end{array}$ & 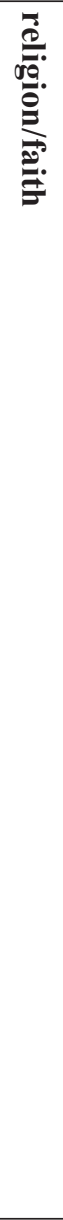 & $\begin{array}{l}\text { Współcześni ludzie nie wierzą. Oni } \\
\text { myślą, że wierzą [...]. (PR III 336) } \\
\text { [Contemporary people don’t believe. } \\
\text { They think that they believe] } \\
\text { Kamieniołom katedry } \\
\text { milczał } \\
\text { wewnątrz } \\
\text { zawieszony na zworniku } \\
\text { kopalny bóg } \\
\text { świecił } \\
\text { białymi żebrami } \\
\text { na dnie } \\
\text { przylepione śliną } \\
\text { do opoki } \\
\text { modliły się } \\
\text { dziwaczne metafizyczne } \\
\text { ssaki } \\
\text { (Kamieniołom, P II 329) } \\
\text { [Quarry of the cathedra } \\
\text { was silent } \\
\text { inside } \\
\text { hung at keystone } \\
\text { fossil god } \\
\text { shone } \\
\text { with white ribs } \\
\text { on the bottom }\end{array}$ \\
\hline
\end{tabular}




\begin{tabular}{|c|c|c|}
\hline & 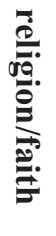 & $\begin{array}{l}\text { stuck with split } \\
\text { to the bedrock } \\
\text { prayed } \\
\text { awkwardly metaphysically } \\
\text { mammals] }\end{array}$ \\
\hline $\begin{array}{l}\text { How the world which became mature, } \\
\text { can be the world of Christ? (Selection } \\
\text { of works, p. 260) } \\
\text { Non-religiousness of a man who beca- } \\
\text { me adult. (Selection of works, p. 271) }\end{array}$ & 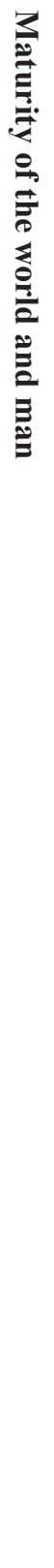 & $\begin{array}{l}\text { Małemu chłopcu w białym ubranku } \\
\text { dano poznać } \\
\text { smak Boga } \\
\text { którego nie ma } \\
\text { I zostałem sam } \\
\text { (Głosy niepotrzebnych ludzi, P I 346) } \\
\text { [A little boy in a white clothing } \\
\text { were allowed to know } \\
\text { the taste of God } \\
\text { which doesn’t exist } \\
\\
\text { And I became alone] } \\
\text { (Voices of the unneeded people) } \\
\text { ojcze Ojcze nasz } \\
\text { [...] } \\
\text { czemuś mnie opuścił } \\
\text { czemu ja opuściłem } \\
\text { Ciebie } \\
\text { [...] } \\
\text { przecież jako dziecko karmiłem się } \\
\text { Tobą } \\
\text { (bez, P III 253) } \\
\text { [father our Father } \\
{[\ldots]} \\
\text { Why did you forsake me } \\
\text { Why did I forsake } \\
\text { You } \\
\text { [...] } \\
\text { In childhood I fed } \\
\text { On You] } \\
\text { (transl. A. Czerniawski) } \\
\text { (Without) } \\
\text { ale w domu nie było Ojca } \\
\text { ani braci ani chleba }\end{array}$ \\
\hline
\end{tabular}




\begin{tabular}{|l|l|}
\hline & $\begin{array}{r}{[\text { Father wasn't at home }} \\
\text { Neither brothers nor bread }] \\
(* * *[\text { Einst hab ich die Muse ge- } \\
\text { fragt...], P III 262-263) }\end{array}$ \\
\hline
\end{tabular}

All the cited poems of Różewicz were written before he could "meet" the author of Disciplinement. The unveiling the monument by Saint Elisabeth Church in Wroclaw took place on $24^{\text {th }}$ April 1999. In learning to walk, written between 2002 and 2004, the poet confessed that he had been taking the "lessons from pastor Dietrich Bonhoeffer" from the "last two years".

Learning to walk opens with two lines of Nächtliche Stimmen in Tegel, a poem written by Bonhoeffer in the Berlin prison in June 1944 (in the same month Gestapo arrested Janusz Różewicz):

„langgestreckt auf meiner Pritsche

starre ich auf die graue Wand"

(Wyciągnięty na pryczy

gapię się w szarą ścianę. $)^{59}$
[Stretched myself out on the bunk

I am glaring at the wall]

Bonhoeffer's lessons start in his cell in Tegel. Tadeusz Różewicz probably read the collection of prison letters, poems and prayers of Nachfolge published by Bethge which after the war were entitled Widerstand und Ergebung ${ }^{60}$. Vestiges of reading of that volume are scattered in the text of learning to walk - in the final part there appears another quotation from Nächtliche Stimmen in Tegel, whereas earlier a transformation and amplification of one of the excerpts of Bonhoeffer's poem:

owinięty w brudny cuchnący koc z zamkniętymi oczami

wsłuchiwał się w szarą ścianę celi oczami wyobraźni malował na niej polne kwiaty modraki kąkole rumianki maki i znów bławatki oczy i usta narzeczonej [wrapped in a stinking blanket his eyes closed he listened to the gray wall of his cell with the eyes of his imagination he painted it in wildflowers cornflowers marigolds chamomiles poppies and more cornflowers the eyes and lips of his bedrothed] (transl. Bill Johnston)

${ }^{59}$ D. Bonhoeffer, Modlitwy $i$ wiersze więzienne, transl. K. Wójtowicz CR, Wydawnictwo Alleluja, Cracow 2005, p. 21. All of the quotations from the Polish translation of the poem Night voices in Tegel I pass according to this edition (pp. 21-27).

${ }^{60}$ D. Bonhoeffer, Widerstand und Ergebung. Briefe und Aufzeichnungen aus der Haft, herausgegeben von Eberhard Bethge, Christian Kaiser Verlag, München 1952. 
The "meeting" of Różewicz and Bonhoeffer was described as a conversation between two living persons. The theologian speaks to the poet, persuades him about the necessity to start "learning to walk / [...] learning to read" again. Różewicz asks questions - among others, about the reason for leaving, God's withdrawal from terrestrial reality. In the poem it wasn't answered, unless one could regard it as putting "finger on the mouth". One should look for it among letters to Bethge, in thoughts Christianity in the epoch of idolatry and genocide, faith mature enough to throw the "costume" of religion off, which are thrown on the paper. Words spoken in learning to walk by Bonhoeffer a reader who is not knowledgeable about Protestant theology of the $20^{\text {th }}$ century could take for the words of the poet himself - they harmonize so well with the vision of world without God presented by Różewicz:

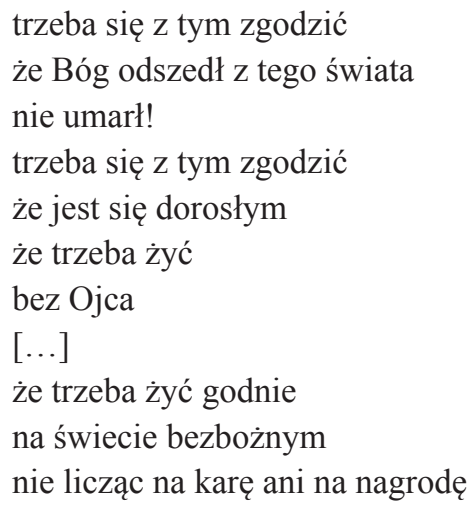

(transl. Bill Johnston)

\author{
[you must accept the fact \\ that God has gone from this world \\ he isn't dead! \\ you have to accept the fact \\ that you're an adult \\ that you have to live \\ without a Father \\ [...] \\ that you have to live with dignity \\ in a godless world \\ without counting on punishments \\ or rewards]
}

The quoted excerpt is composed of two elements: a succinct definition of Bonhoeffer's "non-religious Christianity" and an attempt at formulating superior ethical imperative applying to the godless world. Life of the contemporary man must be based on the awareness that the world became mature. Maturity of the world and man consists of understanding and accepting an essential fact that - "God as a working hypothesis, moral, political, natural, is [...] liquidated, overcame" ${ }^{\prime \prime}$. Probably the most significant in this excerpt of learning to walk is an enjambment which does not occur in the version of the poem published in Wroclaw "Diocesan Year's Issue": "Bóg odszedł z tego świata / nie umarł! / God has gone from this world" / he isn't dead!"

This distinction between "has gone" a "is dead" is meaningful for the interpretation of Różewicz's late works. God is in the world of the $20^{\text {th }}$ and the $21^{\text {st }}$

${ }^{61}$ D. Bonhoeffer, Selection of works, p. 264. 
century absent ("może wystraszył się i opuścił Ziemię?" / "what if God has taken fright and abandoned the Earth?") - but he is alive. What remains to the contemporary man, if he wants to remain a Christian, is to live etsi Deus non daretur.

Bonhoeffer's view about "leaving" of God has its source in the awareness of the changes which occurred in perceiving of the reality from the time when image of the world started to be determined by, among others, developing natural sciences:

A movement aiming at human autonomy (I understand it as inventing the laws according to which the world is governed by in science, social and political life, art, ethics and thanks to which has achieved in our times, at some point, apogee) which started more or less in the thirteenth century (I do not want to go into discussion about the date). Man learnt in all important matters to manage himself, without referring to the "working hypothesis: God". In scientific, artistic and ethical issues it became obvious, which nobody dares to challenge; for more or less one hundred years it has started to concern increasingly religious issues; it results that as everything it functions without "God", and as well as it used to. As well as in the area of science as universal disciplines, God is expelled from life, he has the ground cut from under his feet. ${ }^{62}$

All the revolutionary nature of Bonhoeffer's theses was included in the last two sentences of the excerpt. God has withdrawn, or rather: he has been removed, also from the sphere which has belonged to him so far - religion. He stopped being present in Church as an institution passing on the Christ message and taking care that Christians live as Christians should, that is according to tenacious by tradition religious standards. The Church stopped fulfilling its function and religion did not serve to build a genuine relationship between man and God - it was rather an obstacle in reaching Him. The theologian perceived that process of Christian maturing to the final abandonment the "garment" of religion as imminent, called it achieving by the world is "awareness" 63 .

Bonhoeffer showed Tthe Protestant principle of distinguishing between Order and Gospel, between law and Word of God's mercy as an alternative, which meant juxtaposing Christ to religion ${ }^{64}$. The world has become mature. According to this concept keeping with religion is equivalent to returning to the adolescence, and consequently - going away from God. Meanwhile Christian Churches do not accept changes occurring in the world, "attacking" secular reality, they try to regain their former position. Bonhoeffer judged those actions very critically:

\footnotetext{
${ }^{62}$ Ibidem, p. 252.

${ }^{63}$ Ibidem, p. 253.

${ }^{64}$ B. Milerski, Religia a Stowo. Krytyka religii w ujęciu Dietricha Bonhoeffera i Paula Tillicha, Wydawnictwo Ewangelickie św. Mateusza, Łódź 1994, p. 45.
} 
I find the attack of Christian apologetics to maturity of the world firstly nonsensical, secondly obscene and thirdly non-Christian. It is nonsensical - because it seems to be similar to an attempt of taking back somebody who is an adult person to adolescence, that is making it dependent from things which he isn't dependant to anymore, pushing into problems, which indeed are not his problems. This attack is also obscene because one tries here to use the weakness of a man towards unknown, unconfirmed goals. It is non-Christian because it mixes Christ with a certain stage of human religiousness, that is a certain human right. ${ }^{65}$

A vital argument inducing Bonhoeffer to criticize religion as a human right was the attitude of Christians toward Nazism. War bared all the weaknesses of Church, which not only was unable to set against the evil but several times declared itself in favour of actions of the German state machinery which were completely contradictory to the words of Gospel ${ }^{66}$.

To the fundamental question: "who is Christ for us today?" Bonhoeffer tried to answer in the most exhaustive way because he gave account of the fact that in times when religion does not explain anything, newly defining terms such as "Christianity" and "Christian" is a sine qua non condition of the genuine life according to Gospel. "How one can tell about God - without religion, that is precisely without historically conditioned assumptions of metaphysics, 'internal life', etc.? How should we discuss 'God' 'in a secular way' [...], how can we be 'religious-secular' Christians, and in which way are we to be 'called', not thinking ourselves as religiously privileged, but as belonging to the world?" 67 The category of "secularity" proved to be crucial. Paradoxically it is the entrance into the world, immersing in the unknown element of religion, that was supposed to save man from the final loss of contact with God:

Man has been called to share with God His suffering in the impious world. This man must therefore live in an impious world and he is not allowed to try to hide or camouflage this impiousness. He must live "in a secular way" in which he shares God's suffering. He must and as well he can live in secular way. It means that he is freed from false bond and religious hung-ups. Being a Christian does not mean being religious in any specific way, trying hard, according to a method, to do something with oneself (sinner, penitent or saint). Being Christian means being a human. It is not a type of man but humanity that Christ creates in us. It is not a religious act that makes us Christians, but participation in God's suffering in a secular life. ${ }^{68}$

\footnotetext{
${ }^{65}$ D. Bonhoeffer, Selection of works, p. 253.

${ }^{66}$ Cf. B. Milerski, op. cit., p. 59.

${ }^{67}$ D. Bonhoeffer, Selection of works, p. 240.

${ }^{68}$ Ibidem, pp. 266-267.
} 
In Bonhoeffer's concept the essence of God's suffering depends on His weakness and helplessness towards the impious word, where he was "pushed out" to the cross ${ }^{69}$. It is because of his own helplessness that Jesus makes work of salvation - he is not a God conquering triumphantly the world but a Saviour-sacrifice, which - defeated by the world - he changes with his own pain and abandonment. The author of Nachfolge claimed that reaching maturity by humanity, coming of age by the world means understanding this messianic message: Christians cannot, as so far, appeal to God-ruler of the reality as to dei ex machina, which is "a plug to clog troublesome holes ${ }^{70}$ " but understand and participate in Christ's suffering and helplessness in the world. The primary task of every Christian is therefore to leave false ideas and reach the truth:

God gives us $[\ldots]$ to understand that we should live as people who can manage without Him. The same God which is with us, it is God which leaves us. (Eloi, Eloi lama sabatchani...) The same God, who tells us to live in the world without working „hypothesis of God", is the God before we stand continually. Before God and with God we live without God. ${ }^{71}$

Contemporary man, if he wants to remain a Christian, must therefore - as Różewicz wrote in learning to walk-

żyć godnie

na świecie bezbożnym

nie licząc na karę ani na nagrodę. [live with dignity

in a godless world

without counting on punishments

or rewards]

(transl. Bill Johnston)

To live with dignity means to be with God in his suffering, watch with him in test of time in Gethsemane ${ }^{72}$.

Whatever in Dietrich Bonhoeffer's work is an attempt to create theology in a godless world, in the works of the author of Anxiety is present in fragmentary, repeated time after time - at least from the publication of the collection Regio - poetic and prose depictions of the issue of God's "leaving". As far back as at the twilight of the fifties Różewicz formulated his own version of Bonhoeffer's questions: "Who is Christ for us today?" and "How the world, which has reached its maturity, can be the world of Christ?" - "What is the condition of a man who does not believe in God but he is... a believer?" (PR III 337).

${ }^{69}$ Cf. ibidem, p. 265.

${ }^{70}$ Ibidem, p. 271.

${ }^{71}$ Ibidem, p. 265. Quoted excerpt of Bonhoeffer's letter can serve as astounding commentary to the poem written by Różewicz Without from Low relief.

${ }^{72}$ Cf. ibidem, p. 266. 
The discovery of "godless Christianity" enabled Różewicz to see his own thinking about God and religion in the perspective of the twentieth century theological reflection. The cruciality of that discovery lied in its anamnestic dimension - the poet, so to speak, returned to the starting point

(i znalazłem się nagle w świetle w krainie młodości w ziemskim raju odnalazłem oczy i usta mojej dziewczyny i chabry i obłoki), [(and found myself suddenly in the light in the light of childhood in an earthy paradise I recovered the eyes and lips of my girl and cornflowers and clouds),]

(transl. Bill Johnston)

he realised that the way from traditional religiousness to Christianity after God's leaving, with its necessary stage - apostasy, was not a spiritual chaotic desire, accidental but it was a process ${ }^{73}$.

Obviously, it does not mean that restoring the original state of faith is possible - it would not be authentic faith but a kind of artificial limb. Różewicz was, in fact, completely critical to "such sudden illuminations as that which Paul Claudel experienced, and with him many other French intellectuals - those can be called specialists of sudden conversions and extraordinary experiences connected with it" (WS 248). The meeting with Bonhoeffer surely should not be considered as reformation. The experience of the poet did not mean metanoia. Taking into consideration the procedural character of that experience, one could even acknowledge - according to the concept of the Autor of Life Together - that atheism declared formerly by Różewicz was a necessary condition of achieving "maturity". Only immersing in the world, agreeing to God's leaving and interior orphanhood, man can restore his relation with Christ. Its constructive element is suffering.

Contemporary human can with Christ go through the torment of Calvary. The source of this suffering is godless world, where God became needless where - as Bonhoeffer said - was "pushed" onto the cross. As a remain of that suffering dealt by the reality deprived of contact with God one could recognize in Różewicz's output those works, in which a longing for "terrestrial paradise", "land of youth" with a belonging sense of safety and order become prominent. In one of the most moving excerpts of Sheets of paper torn from "Gliwice journal"

\footnotetext{
${ }^{73}$ Such knowledge the poet did not possess a dozen or so years earlier when in a conversation with Richard Sokoloski he called this poem Without from Low relief"suspect" and claimed that: "Materialist, rationalist, sensualist lying in me looks mistrustfully at the process occurring in me. I am trying even to hold it back, nevertheless my awareness stands crossways to something that comes out from subconsciousness, which remained in me from the youth, this primordial" (WS 247).
} 
the poet reached to - so close to the theology of Bonhoeffer - differentiating between "being a child" and "being an adult":

God, how difficult it is. It seems to me that as long as my mother lived, I was a child - when she died, I became an adult. Life of adult "man" is terrible. [...]

As many times the "adult" issues begin, as many times I become bad and stupid man. I can say about myself that I am being "adult" man, but these are bad moments for me. In the depths of my soul I hate the world of adults. [...]

Everything that I am writing, is rotating around. I cannot open it. I cannot enter. Would the entry be booked only for the mystics and madmen, for children? I am a false child. Even if I have the best intentions. Children, madmen, soldiers - entry for a half of price.

No. I cannot so! I cannot. There is something bad in it. Something has broken. Is it world? Is it me? Go on. Get up. Move. Serve.

But they had Lord. We are without Lord. Can we serve and can we leave? Where? I wanted to write a few insults for me... but it is enough that I repeat it often. Now also. (PR II 335)

Here it is worth paying attention to the vital element of Różewicz, which is another "point of contact" with Bonhoeffer's theology - using paradox, aporia, internal contradiction. It becomes especially visible in poems about religion, faith and relations / lack of relations man-God. The couplet

życie bez boga jest możliwe

życie bez Boga jest niemożliwe

(bez, P III 254) [life without god is possible

life without god is impossible] (transl. A. Czerniawski)

illustrates well this technique, the most essential function of which is signalling a dichotomy: no thought and no judgement should be treated as unambiguous and final - the poet appears to recall. From the earlier poems a similar structure has Thorn from the collection Regio ${ }^{74}$, where after repeated many times non credo goes the following declaration:

myślę o małym

bogu krwawiącym

w białych

chustach dzieciństwa
[I think of the small god bleeding

amid white

sheets of childhood

${ }^{74}$ Cf. W. Gutowski, op. cit., p. 127. The researcher wrote about the ending of Thorn, that "[it] particularly dramatises the profession of non-faith and undermines it in a way". 


\author{
o cierniu który rozdziera \\ nasze oczy usta \\ teraz \\ i w godzinie śmierci
}

(P III 39) or the thorn which tears

our eyes and lips

now

and in the hour of our death]

(transl. A. Czerniawski)

In learning to walk Tadeusz Różewicz referred not only to the letters from Tegel but also to Disciplineship (Nachfolge), written by Bonhoeffer in the time of working at the preacher seminary in Finkenwalde. That theological explication of Christ's Sermon on the Mount is one of the most recognisable books of Bonhoeffer, and included in it terms of "expensive mercy" and "cheap mercy" for good were introduced into the dictionary of contemporary Protestant thought. At the moment of its publication and through many years it was read according to the political key, treating views included in it as a direct reaction to Nazism and an increasing degradation of the Church in the Third Reich. Emulating Christ, unconditional following Him is - according to the author of Disciplineship - the only condition of saving Christian identity in times when faith and growing out of its ethics are being trampled and ousted from human life. Nachfolge was an attempt to show the way of holiness of man among hostility towards Christian reality of the second half of the 1930s in Nazi Germany.

Those efforts whose testimony is a book about following Jesus, Bonhoeffer himself a few years later was willing to treat critically. In a letter to Bethge written in Tegel in 1944 he comprehended the essence of "emulating" in a different way - as deliberate entering the godless world:

Christian [...] must drink up terrestrial life, after Christ ("My God, why have you forsaken me"?), and only when he does it, is accompanied by Crucified and Resurrected and he himself is crucified and resurrected with Christ. It is not possible to invalidate prematurely mortal life. That is just where the New Testament combines with the New Testament. Myths of salvation arise from human experience of limit. However, Christ appropriates a man in the middle of life. ${ }^{75}$

The primacy of mortal life, this here and now, separating from the metaphysics, emphasizing the meaning of ethics in a human life - so important for Bonhoeffer's later works - those are as well the vital elements of Różewicz writing. "The source of output - I thought [just after the war] - can be only ethics. [...] Therefore, I tried to rebuild all this, which seemed to me the most important for life and poetry. Ethics. [...] For my poetic output was only action. [...]. No poems, but facts" (PR III 145) - the poet wrote in 1965.

\footnotetext{
${ }^{75}$ D. Bonhoeffer, Selection of works, p. 257.
} 
"Disciplineship" is one of the key words in the collection Exit (See poems ***[Dostoyevsky said...], learning to walk and ***[since when this ,,kid"...]). In the ending of learning to walk Bonhoeffer is somebody who:

\author{
szedł za Chrystusem \\ naśladował Chrystusa \\ szedł polną drogą z innymi \\ uczniami głodni rwali \\ dojrzałe kłosy \\ łuskali ziarno jedli \\ $\mathrm{z}$ dłoni
}

\author{
[followed Christ \\ emulated Christ
}

he walked across a field with other students hungry they picked

ripe ears of corn

husked the grains ate them

with their fingers]

(transl. Bill Johnston)

Following the Saviour appears as a condition of restoring original unity with God and rebuilding a harmonious vision of world and human. Making an attempt of "emulating" by the lyrical subject, following Bonhoeffer (Christ?) "and other disciples" ("próbowałem ich dogonić" / "I tried to catch up with them"), leads to restoration - at least for a moment - of a pre-apocalyptic vision of the world ("znalazłem się nagle w świetle"/ "I found myself suddenly in the light). Thus the lessons in "walking" also prove to be lessons in "emulating".

The poem referring to the theological and anthropological concepts of Dietrich Bonhoeffer is a centre of Różewicz's collection of poems Exit. Without "learning to walking" movement would be possible (even this one, which was named with a title word). What is that "exit"? We find a tip in the letter of the author of Life Together to Eberhard Bethge of $16^{\text {th }}$ July 1944 (in the same letter "overcoming God as a working hypothesis" is mentioned):

Where therefore is the place for God? Timid souls as but they cannot find the answers, condemn all the process which introduced them into such troublesome situation.

As I have already written, what I think about different emergency exits from this, so tightening "divine" space. It should be added that there is a possibility of salto mortale back to the Middle Ages. [...] [It] is a dream to melody: "I wish I knew the way back, long way to land of my childhood".

Therefore, there is no other way, in any case it cannot lead through giving up forcibly from internal honesty, and only through penance, that is through final honesty. ${ }^{76}$

„Exit” means then, firstly, making an effort, the final goal of which is to find God - in the world and our life. It is a question about His presence among

\footnotetext{
${ }^{76}$ Ibidem, p. 264.
} 
useless props of religion, crying from depth of doubt. The path cannot lead to the beginning, towards naive faith like child's faith. By looking back one can feel and understand better the situation of a man who "became an adult".

„Exit" is also the leaving of Jerusalem after Christ's death and wandering, being on the way - to Emmaus. The poet met Bonhoeffer there, who "explains [him] scripture", as formerly Jesus to Cleophas and Simon. Are - like before - the eyes of the pilgrim "covered"? Would he still not be able to answer the question: "Who is the third, who always wanders with you"?

"Exit" can be understood as immersing into darkness of absent God, taking a burden of one's freedom, an Abrahamic act of leaving security, place, which one used to consider home - Abraham left Chaldean Ur to find the only God and become father of the chosen people, the tribe of God's wanderers ${ }^{78}$. The poet, as a patriarch from the Old Testament, agrees on an indefinite shape of the future - setting off in a way is a great opening, without guarantee of closing ${ }^{79}$. In this effort of restarting accompanies him the „Lutheran saint”, Dietrich Bonhoeffer - "inspirer of the post-war formations of radical resignations, 'exodus' straight to the unknown" (Morawska, p. 13).

\section{Bibliography}

Braun Kazimierz, Różewicz Tadeusz, Języki teatru, Wydawnictwo Dolnośląskie, Wroclaw 1989. Drewnowski Tadeusz, Walka o oddech. Bio-poetyka. O pisarstwie Tadeusza Różewicza, Wydawnictwo Literackie, Cracow 2002.

Fiut Aleksander, Po śmierci Boga (O twórczości Tadeusza Różewicza), “Teksty Drugie” 1993, issue 3, pp. 22-34.

Gutowski Wojciech, Aluzje biblijne i symbolika religijna w poezji T. Różewicza, in: idem, Wśród szyfrów transcendencji. Szkice o sacrum chrześcijańskim w literaturze polskiej XX wieku, Wydawnictwo UMK, Toruń 1994, pp. 117-176.

${ }^{77}$ Cf. R. Przybylski, op. cit., p. 126.

${ }^{78}$ Is using the word "exit" as title of the collection of poems also equivalent to citing a source myth of the European culture - leaving "the house of bondage" (in Różewicz: godless world)? If so, poems from Exit should be recognised as an element of a further process of resacralisation of the contemporary culture. Cf. A. Bielik-Robson, Inna nowoczesność. Pytania o wspótczesna formułe duchowości, Universitas, Cracow 2000, p. 360.

${ }^{79}$ Myth of Exit - Agata Bielik-Robson pointed out - as a "metaphor of human condition who in everything that he does, is doomed - completely consciously for himself - to_non-commitment", includes typical of myths "agreement on ambivalence and incomplete ordering of the world" (ibidem). In Exit the poet does not answer unambiguously - each "yes" corresponds to "no": poem ***[Whiteness doesn't sudden...] was made available to the reader in two versions: white letters in a black background (facsimile of the manuscript - mould) and usual print; Angel the guardian of the poet from the poem my poor Angel the Guardian is accompanied by Devil the Guardian; a Christmas dream about God was named in title-commentary Fairy tale; on the last page of the cover there was an unique additional mould to the title of the collection of poems: "... and entry". 
Heck Dorota, Różewicz mistyczny (Z notatek), “Teksty Drugie” 1994, issue 2, pp. 142-148.

Kłak Tadeusz, Spojrzenia. Szkice o poezji Tadeusza Różewicza, Biblioteka Śląska, Katowice 1999. Majchrowski Zbigniew, Różewicz, Wydawnictwo Dolnośląskie, Wroclaw 2002.

Nawrocka Ewa, Mówienie ze środka klęski, “Tytuł” 1992, issue 1, pp. 121-127.

Przybylski Ryszard, Droga do Emaus, "Odra" 1970, issue 5, pp. 125-127.

Różewicz Tadeusz, odpowiedź na ankietę Chrystus w oczach niechrześcijan, "Znak" 1998, issue 10, pp. 41.

Różewicz Tadeusz, Utwory zebrane, vol. I-XII, Wydawnictwo Dolnośląskie, Wroclaw 2003-2006.

Skrendo Andrzej, Tadeusz Różewicz i granice literatury. Poetyka i etyka transgresji, Universitas, Cracow 2002.

Bethge Eberhard, Dietrich Bonhoeffer. Świadek Ewangelii w trudnych czasach, transl. ks. B. Milerski, Augustana, Bielsko-Biała 2003.

Bielik-Robson Agata, Inna nowoczesność. Pytania o wspótczesna formułę duchowości, Universitas, Cracow 2000.

Bonhoeffer Dietrich, Modlitwy i wiersze więzienne, transl. K. Wójtowicz CR, Wydawnictwo Alleluja, Cracow 2005.

Bonhoeffer Dietrich, O odpowiedzialności, transl. J. Filek, Redakcja Miesięcznika "Znak”, Cracow 2001.

Bonhoeffer Dietrich, Widerstand und Ergebung. Briefe und Aufzeichnungen aus der Haft, herausgegeben von Eberhard BethgeChristian Kaiser Verlag, München 1952.

Bonhoeffer Dietrich, Wybór pism, wybór, introductory notes by Anna Morawska (ed.), Znak, Cracow 1969.

Davies Norman, Moorhouse Roger, Mikrokosmos. Portret miasta środkowoeuropejskiego. Vratislavia-Breslau-Wroctaw, transl. A. Pawelec, Znak, Cracow 2002.

Goebbels Joseph, Die Tagebücher: Sämtliche Fragmente, E. Fröhlich (ed.), München 1987.

Milerski Bogusław, Religia a Stowo. Krytyka religii w ujęciu Dietricha Bonhoeffera i Paula Tillicha, Wydawnictwo Ewangelickie św. Mateusza, Łódź 1994.

Morawska Anna, Chrześcijanin w Trzeciej Rzeszy, Biblioteka "Więzi”, Warsaw 1970.

Napiórkowski Andrzej OSPPE, Wstęp, in: D. Bonhoeffer, Życie wspólne, transl. K. Wójtowicz, Wydawnictwo Alleluja, Cracow 2001.

Podgórzec Zbigniew, Mój Chrystus. Rozmowy z Jerzym Nowosielskim, Wydawnictwo Luk, Białystok 1993.

Steinert Marlis, Hitler, transl. K. Skawina, Ossolineum, Wroclaw 2001.

Wiosenna sesja Synodu Diecezji Wroctawskiej, “Zwiastun Ewangelicki” 2005, issue 7, pp. 19-20. 
Przemysław Dakowicz

\title{
Różewicz and Bonhoeffer. On the Margin of the Poem Learning to Walk by Tadeusz Różewicz
}

\author{
(Summary)
}

The departure point of the analysis presented in this article is a poem written by Tadeusz Różewicz learning to walk (nauka chodzenia). The protagonist of the poem is Dietrich Bonhoeffer, who created the theory of "religionless Christianity". According to Bonhoeffer, a modern Christian has to immerse himself/herself in the "godless" world so that - in tandem with the Saviour - he/she can be experience the final abandonment.

The author of this article tries to prove that the theology of Bonhoeffer had a great impact on Różewicz, making him reconsider his viewpoint on faith. Due to Dietrich Bonhoeffer, the poet also found a solution for a basic contradiction that was explicated in the famous poem entitled $\mathrm{Bez}$ (Without): "life without god is possible / life without god is impossible".

Keywords: Tadeusz Różewicz, Dietrich Bonhoeffer, learning to walk 